Editorial

\title{
Recent Progress and Developments in Imaging Spectroscopy
}

\author{
Mathias Kneubühler ${ }^{1, *(1)}$ and Alexander Damm-Reiser ${ }^{1,2}$ \\ 1 Remote Sensing Laboratories, Department of Geography, University of Zurich, Winterthurerstrasse 190, \\ 8057 Zürich, Switzerland; alexander.damm@geo.uzh.ch \\ 2 Eawag, Swiss Federal Institute of Aquatic Science and Technology, Überlandstrasse 133, \\ 8600 Dübendorf, Switzerland \\ * $\quad$ Correspondence: mathias.kneubuehler@geo.uzh.ch; Tel.: +41-44-635-52-46
}

Received: 12 September 2018; Accepted: 18 September 2018; Published: 19 September 2018

The Special Issue (SI) on "Recent Progress and Developments in Imaging Spectroscopy" is a collection of contributions presented at the 10th Workshop of the European Association of Remote Sensing Laboratories (EARSeL) Special Interest Group on Imaging Spectroscopy (SIG IS), which took place at the University of Zurich, Zurich, Switzerland, between 19 and 21 April 2017. Moreover, the SI was equally open to the global research community actively involved in imaging spectroscopy. EARSeL's Special Interest Group on Imaging Spectroscopy aims at encouraging interdisciplinary discussions among specialists working with innovative Earth observation methods and technologies. With its 10th workshop in April 2017, the EARSeL SIG IS workshop series celebrated its 20th anniversary, building on the legacy of nine successful previous workshops, whereas the first one took place at the University of Zurich back in 1998.

Most of the contributions to this SI can be closely linked to the overarching main workshop topics including (i) advanced methods for sensor calibration, data processing, and archiving, (ii) integrated approaches in Earth system science using spectroscopy, and (iii) next generation platforms and sensors.

Imaging spectroscopy increasingly finds its way into interdisciplinary research aiming to integrate state-of-the art observational methods and data analysis concepts with process modeling in response to today's key environmental and societal challenges. Increasing awareness and capacity for accurate sensor calibration and rigorous product validation by an expanding research community [1] and innovative approaches integrating different Earth observation technologies (e.g., LIDAR, spectroscopy, etc.) allow for novel observations of the Earth system [2-4]. Imaging spectroscopy is increasingly combined with concepts of Earth system science to study ecosystem processes [5-7] and functions [4,8,9], quantify interactions and feedback mechanisms between and across Earth spheres [10,11], spatially explicit and continuously map ecosystem services [12,13], and to facilitate research in the context of societal challenges (e.g., water scarcity [10] or biodiversity loss [4,9]). New sensor developments in space will provide future spectroscopy data for key observations of the Earth's spheres (e.g., the EnMap mission (DLR), the PRISMA mission (ASI), the Fluorescence Explorer mission (ESA), the Hyperspectral Imager Suite (HISUI) mission (Japanese Ministry of Economy, Trade and Industry) onboard the International Space Station (ISS), or the European Copernicus Programme expansion Sentinel candidate CHIME).

The contributions to the SI on "Recent Progress and Developments in Imaging Spectroscopy" comprise three review articles and 12 research works. The review article by Aasen et al. [14] provides an extensive overview on quantitative remote sensing at ultra-high resolution with unmanned aerial vehicle (UAV) based spectroscopy. It investigates a wide range of sensor technologies, including light-weight spectrometers, measurement procedures, and data correction workflows, and outlines trends, potential opportunities, and limitations of actual UAV based technology. 
The review by Rautiainen et al. [15] assesses the current knowledge of radiation interaction with a coniferous forest by systematically investigating the spectral behavior of its different components. It reports on selected case studies employing in situ and laboratory measurements and treats spatial, directional, and seasonal variations of the various elements of coniferous stands.

The third review provided by Berger et al. [16] evaluates the PROSAIL radiative transfer model capabilities for future hyperspectral model environments. The authors carried out a systematic literature review of scientific publications and they conclude that the model is well suited to facilitate agricultural applications by supporting the analysis of imaging spectrometer data from future satellite missions.

The 12 research articles contained in this SI cover imaging spectroscopy data processing issues (e.g., radiometric characterization, correction, and modeling) as well as applications and case studies mainly related to the biosphere and pedosphere. In Mihai et al. [17], the authors compare wavelength calibration approaches and develop recommendations for the spectral characterization of field fixed-point spectrometers used for reflectance and sun-induced fluorescence (SIF) measurements in support of the European Space Agency (ESA) Fluorescence Explorer (FLEX) mission.

In Hovi et al. [18], the authors evaluate the accuracy and practical applicability of three different methods for measuring leaf reflectance and transmittance spectra. They conclude on within- and between-method variability of a single integrating sphere, a double integrating sphere, and a leaf clip.

The article by Honkavaara and Khoramshahi [19] presents an optimization approach for the radiometric correction of UAV spectral image blocks that can deal with data acquired under varying illumination conditions and cloudiness. Their study is an important contribution to the processing of close-range 2D frame format image datasets captured using drones.

The contribution by Salehi et al. [20] highlights the potential of integrating vessel based hyperspectral scanning and 3D photogrammetry to map steep coastal cliffs in the Arctic. The authors indicate that horizontal viewing geometry from mobile platforms in combination with multi-source and multi-scale data fusion approaches has potential for regional mineral mapping.

Schläpfer et al. [21] propose a cast shadow based aerosol optical thickness estimation method to quantify the aerosol optical thickness for atmospheric correction of high spatial resolution optical imagery. The approach, tested on airborne imaging spectroscopy and photogrammetric data, leads to improved accuracy of reflectance values obtained from atmospheric correction.

Verrelst et al. [22] propose a methodology for the fast generation of synthetic canopy reflectance spectra and SIF spectra using machine learning emulators based on the SCOPE energy balance model. They conclude that a substantial reduction in processing time is possible (i.e., from days down to minutes) when an emulator is used as an alternative to the SCOPE model. Errors introduced by the emulator are below $2 \%$ for reflectance and $4 \%$ for SIF along the spectral range.

The contribution by Martin et al. [23] reports on the performance of the Spectranomics approach for foliar trait retrieval newly applied to the humid tropical forests of Malaysian Borneo. The results are similar to those of previous studies in Neotropical forests and the authors conclude on the more general use of their approach for mapping canopy traits in tropical forests.

In Markiet et al. [24], the authors successfully quantified the extent to which the sunlit fraction alone of a Boreal forest stand can describe variations in the photochemical reflectance index (PRI), being a proxy for light use efficiency (LUE). Their results suggest a scatter angle dependent and non-linear relationship between PRI and sunlit fraction and indicate the need of PRI-sunlit fraction relationships to quantify PRI variations of forest canopies.

The article by Kycko et al. [25] deals with the assessment of the impact of tourist traffic on the condition of Alpine grassland. The study performed in the High Tatras in Poland focuses on high-resolution spectral properties of plants along tourist trails. Results indicate that dependent on species, vegetation tends to adapt to trampling.

Vohland et al. [26] report on the quantification of soil properties (i.e., microbial biomass-C, hot water-extractable $\mathrm{C}$, organic carbon, nitrogen) using both laboratory and airborne imaging spectroscopy 
data. They conclude on the usefulness of airborne imaging spectroscopy to quantify key soil properties, especially organic carbon and microbial biomass-C.

A further study, authored by Castaldi et al. [27], also deals with the estimation of soil organic carbon (SOC) using imaging spectroscopy data. The proposed methodology allows for the generation of SOC maps of bare cropland fields without chemical analysis, rather employing the pan-European topsoil database from the Land Use/Cover Area frame statistical Survey (LUCAS) and airborne imaging spectroscopy data.

Last but not least, the article by Carmon and Ben-Dor [28] evaluates the feasibility of mapping asphaltic road's transportation safety using airborne imaging spectroscopy data. By modeling the road-tire friction against reflectance information using a spectral data mining engine, the authors are able to predict and map the friction values of every pixel in their scene. They conclude on possible improvements by incorporating thermal data, LIDAR data, and UAV platforms.

Author Contributions: The two authors contributed equally to all aspects of this editorial.

Funding: This research received no external funding.

Acknowledgments: The authors thank the various contributors, reviewers, and journal staff at MDPI Remote Sensing for making this Special Issue a success. We are grateful to the many volunteers from the Remote Sensing Laboratories (RSL), University of Zurich, Zurich, Switzerland, for their technical and administrative support prior to and during the 10th EARSeL SIG IS Workshop (19-21 April 2017). The EARSeL Bureau is thanked for their great support to the workshop organization. The University of Zurich is thanked for providing its premises and technical support to the workshop.

Conflicts of Interest: The authors declare no conflict of interest.

\section{References}

1. Hueni, A.; Damm, A.; Kneubuehler, M.; Schläpfer, D.; Schaepman, M.E. Field and airborne spectroscopy cross validation-Some considerations. IEEE J. Sel. Top. Appl. Earth Obs. Remote Sens. 2017, 10, 1117-1135. [CrossRef]

2. Asner, G.P.; Knapp, D.E.; Boardman, J.; Green, R.O.; Kennedy-Bowdoin, T.; Eastwood, M.; Martin, R.E.; Anderson, C.; Field, C.B. Carnegie airborne observatory-2: Increasing science data dimensionality via high-fidelity multi-sensor fusion. Remote Sens. Environ. 2012, 124, 454-465. [CrossRef]

3. Stavros, E.N.; Schimel, D.; Pavlick, R.; Serbin, S.; Swann, A.; Duncanson, L.; Fisher, J.B.; Fassnacht, F.; Ustin, S.; Dubayah, R.; et al. ISS observations offer insights into plant function. Nat. Ecol. Evol. 2017, 1, 0194. [CrossRef] [PubMed]

4. Schneider, F.D.; Morsdorf, F.; Schmid, B.; Petchey, O.L.; Hueni, A.; Schimel, D.S.; Schaepman, M.E. Mapping functional diversity from remotely sensed morphological and physiological forest traits. Nat. Commun. 2017, 8, 1441. [CrossRef] [PubMed]

5. Ustin, S.L.; Roberts, D.A.; Gamon, J.A.; Asner, G.P.; Green, R.O. Using imaging spectroscopy to study ecosystem processes and properties. BioScience 2004, 54, 523-534. [CrossRef]

6. Zhang, Y.; Guanter, L.; Berry, J.A.; Joiner, J.; Tol, C.; Huete, A.; Gitelson, A.; Voigt, M.; Köhler, P. Estimation of vegetation photosynthetic capacity from space-based measurements of chlorophyll fluorescence for terrestrial biosphere models. Glob. Chang. Biol. 2014, 20, 3727-3742. [CrossRef] [PubMed]

7. Qiu, B.; Xue, Y.; Fisher, J.B.; Guo, W.; Berry, J.A.; Zhang, Y. Satellite chlorophyll fluorescence and soil moisture observations lead to advances in the predictive understanding of global terrestrial coupled carbon-water cycles. Glob. Biogeochem. Cycles 2018, 32, 360-375. [CrossRef]

8. Schweiger, A.K.; Schütz, M.; Risch, A.C.; Kneubühler, M.; Haller, R.; Schaepman, M.E. How to predict plant functional types using imaging spectroscopy: Linking vegetation community traits, plant functional types and spectral response. Methods Ecol. Evol. 2017, 8, 86-95. [CrossRef]

9. Schweiger, A.K.; Cavender-Bares, J.; Townsend, P.A.; Hobbie, S.E.; Madritch, M.D.; Wang, R.; Tilman, D.; Gamon, J.A. Plant spectral diversity integrates functional and phylogenetic components of biodiversity and predicts ecosystem function. Nat. Ecol. Evol. 2018, 2, 976-982. [CrossRef] [PubMed] 
10. Damm, A.; Paul-Limoges, E.; Haghighi, E.; Simmer, C.; Morsdorf, F.; Schneider, F.D.; van der Tol, C.; Migliavacca, M.; Rascher, U. Remote sensing of plant-water relations: An overview and future perspectives. J. Plant Physiol. 2018, 227, 3-19. [CrossRef] [PubMed]

11. Green, J.K.; Konings, A.G.; Alemohammad, S.H.; Berry, J.; Entekhabi, D.; Kolassa, J.; Lee, J.-E.; Gentine, P. Regionally strong feedbacks between the atmosphere and terrestrial biosphere. Nat. Geosci. 2017, 10, 410. [CrossRef]

12. Braun, D.; Damm, A.; Paul-Limoges, E.; Revill, A.; Buchmann, N.; Petchey, O.L.; Hein, L.; Schaepman, M.E. From instantaneous to continuous: Using imaging spectroscopy and in situ data to map two productivity-related ecosystem services. Ecol. Indic. 2017, 82, 409-419. [CrossRef]

13. Braun, D.; Damm, A.; Hein, L.; Petchey, O.L.; Schaepman, M.E. Spatio-temporal trends and trade-offs in ecosystem services: An earth observation based assessment for switzerland between 2004 and 2014. Ecol. Indic. 2018, 89, 828-839. [CrossRef]

14. Aasen, H.; Honkavaara, E.; Lucieer, A.; Zarco-Tejada, P. Quantitative remote sensing at ultra-high resolution with uav spectroscopy: A review of sensor technology, measurement procedures, and data correction workflows. Remote Sens. 2018, 10, 1091. [CrossRef]

15. Rautiainen, M.; Lukeš, P.; Homolová, L.; Hovi, A.; Pisek, J.; Mõttus, M. Spectral properties of coniferous forests: A review of in situ and laboratory measurements. Remote Sens. 2018, 10, 207. [CrossRef]

16. Berger, K.; Atzberger, C.; Danner, M.; D’Urso, G.; Mauser, W.; Vuolo, F.; Hank, T. Evaluation of the prosail model capabilities for future hyperspectral model environments: A review study. Remote Sens. 2018, 10, 85. [CrossRef]

17. Mihai, L.; Mac Arthur, A.; Hueni, A.; Robinson, I.; Sporea, D. Optimized spectrometers characterization procedure for near ground support of esa flex observations: Part 1 spectral calibration and characterisation. Remote Sens. 2018, 10, 289. [CrossRef]

18. Hovi, A.; Forsström, P.; Mõttus, M.; Rautiainen, M. Evaluation of accuracy and practical applicability of methods for measuring leaf reflectance and transmittance spectra. Remote Sens. 2018, 10, 25. [CrossRef]

19. Honkavaara, E.; Khoramshahi, E. Radiometric correction of close-range spectral image blocks captured using an unmanned aerial vehicle with a radiometric block adjustment. Remote Sens. 2018, 10, 256. [CrossRef]

20. Salehi, S.; Lorenz, S.; Vest Sørensen, E.; Zimmermann, R.; Fensholt, R.; Henning Heincke, B.; Kirsch, M.; Gloaguen, R. Integration of vessel-based hyperspectral scanning and 3D-photogrammetry for mobile mapping of steep coastal cliffs in the arctic. Remote Sens. 2018, 10, 175. [CrossRef]

21. Schläpfer, D.; Hueni, A.; Richter, R. Cast shadow detection to quantify the aerosol optical thickness for atmospheric correction of high spatial resolution optical imagery. Remote Sens. 2018, 10, 200. [CrossRef]

22. Verrelst, J.; Rivera Caicedo, J.; Muñoz-Marí, J.; Camps-Valls, G.; Moreno, J. Scope-based emulators for fast generation of synthetic canopy reflectance and sun-induced fluorescence spectra. Remote Sens. 2017, 9, 927. [CrossRef]

23. Martin, R.; Chadwick, K.; Brodrick, P.; Carranza-Jimenez, L.; Vaughn, N.; Asner, G. An approach for foliar trait retrieval from airborne imaging spectroscopy of tropical forests. Remote Sens. 2018, 10, 199. [CrossRef]

24. Markiet, V.; Hernández-Clemente, R.; Mõttus, M. Spectral similarity and pri variations for a boreal forest stand using multi-angular airborne imagery. Remote Sens. 2017, 9, 1005. [CrossRef]

25. Kycko, M.; Zagajewski, B.; Lavender, S.; Romanowska, E.; Zwijacz-Kozica, M. The impact of tourist traffic on the condition and cell structures of alpine swards. Remote Sens. 2018, 10, 220. [CrossRef]

26. Vohland, M.; Ludwig, M.; Thiele-Bruhn, S.; Ludwig, B. Quantification of soil properties with hyperspectral data: Selecting spectral variables with different methods to improve accuracies and analyze prediction mechanisms. Remote Sens. 2017, 9, 1103. [CrossRef]

27. Castaldi, F.; Chabrillat, S.; Jones, A.; Vreys, K.; Bomans, B.; van Wesemael, B. Soil organic carbon estimation in croplands by hyperspectral remote apex data using the lucas topsoil database. Remote Sens. 2018, 10, 153. [CrossRef]

28. Carmon, N.; Ben-Dor, E. Mapping asphaltic roads' skid resistance using imaging spectroscopy. Remote Sens. 2018, 10, 430. [CrossRef]

(C) 2018 by the authors. Licensee MDPI, Basel, Switzerland. This article is an open access article distributed under the terms and conditions of the Creative Commons Attribution (CC BY) license (http://creativecommons.org/licenses/by/4.0/). 